\title{
The Higher Education Academic Readiness of Students in the United States
}

\author{
Ronald Carlson ${ }^{1}$, Christopher McChesney ${ }^{1}$ \\ ${ }^{1}$ Indian River State College, School of Business, 3209 Virginia Ave., Fort Pierce, FL 34981 USA. \\ Correspondence: Christopher McChesney, ${ }^{1}$ Indian River State College, School of Business, 3209 Virginia Ave., Fort \\ Pierce, FL 34981 USA.
}

Received: June 12, 2016 Accepted: June 27, $2016 \quad$ Online Published: July 14, 2016

doi:10.11114/jets.v4i8.1737 URL: http://dx.doi.org/10.11114/jets.v4i8.1737

\begin{abstract}
The authors examined the state of United States student academic readiness for higher education from a global perspective utilizing data from the Organization of Economic and Co-operation and Development (OECD) and Programme for International Student Assessment (PISA), which tests over a half a million 15 year old student's skills and knowledge. These scores were compared to the expenditures per student according to GDP growth and relation to U.S. dollars to draw conclusions. While it is true that the United States is among the top nations in terms of expenditures per student per year, the United States does not score in the top nations when tested by PISA. The author's did not find a correlation between the Gross Domestic Product (GDP) growth rate and the PISA Scores. The authors also examined several OECD studies across age groups and national performance and the United States students performed below the national averages. The authors, however, suggest that the declining average GDP growth rates and deteriorating standard of living in the United States are related in part, to the weakening academic performance in the United States. While the statistical correlation between academic performance and economic growth rates has not been proven, the United States mediocre test results are still disquieting. It may prove true that it will take several decades before the correlation becomes statistically evident and, at that point, it may take a generation, or much more, for the United States to recover and become competitive globally once again.
\end{abstract}

Keywords: OECD, PISA scores, student readiness, higher education, GDP growth, United States academic readiness

\section{Introduction}

\subsection{The Problem}

The continuing poor performance of students and the general population in the United States on international standardized testing has implications in many areas. The area examined in this study is the low test scores impact on the United States Gross Domestic Product (GDP) growth rate.

\subsection{Relevant Scholarship}

A foundational knowledge of comparative education is necessary to better understand the way in which the various pieces of the education puzzle fit together. This includes the ranking of the nation States in mathematics, science, and reading, at an absolute minimum, as well as the contemporary historical rankings of the nation States, in an effort to establish a trend.

\subsection{Educational Funding}

A nation's funding and position on the importance of critical thinking, open-mindedness, and continual Socratic learning is paramount to building and continually improving an educational system. The funding for education must be applied for the betterment of the student's foundational knowledge rather than political expedient "action" that satisfies the short term goals of the government. This is demonstrated by the large sums spent on education per capita in the United States which is resulting in weakening academic test scores. The author in the article, Does money buy strong performance in PISA (OECD, 2012) compares the average reading scores from PISA (Programme for International Student Assessment ) 2009 based on per capita GDP income and cumulative expenditure on education by country, dividing the countries into two categories, above and below $\$ 20,000$ per capita income. The results show in nations below $\$ 20,000$ per capita income, the per capita is a strong positive indicator of the PISA reading score. For example, 
when comparing Poland and Peru in reading, Poland has a per capita income twice as high, with a PISA score over 100 points higher, which correlates per capita and test results. On the other hand, the per capita income has very little impact on the PISA reading scores in countries with a per capita above $\$ 20,000$. For example, Estonia, with a per capita of approximately $\$ 21,000$, and the United States, with a per capita of approximately $\$ 47,000$, have essentially the same PISA reading scores. Interestingly, the same was true of the level of total expenditures per student from 6 to 15 years of age. Countries spending less than $\$ 35,000$ show a positive correlation to the PISA reading score, while there is very little correlation in countries spending more than $\$ 35,000$. (PISA 2012).

Comparing the national expenditures per full time equivalent student in relation to the GDP illustrates the annual financial investment in preparation for tertiary education. Luxembourg ranks the highest in spending at $\$ 20,153$, Norway ranks second highest at $\$ 13,611$, while the United States ranks $3^{\text {rd }}$ at $\$ 11,732$ per student. On the lower end of the scale, Indonesia ranks lowest in spending at $\$ 1,096$, Turkey ranks second lowest at $\$ 2,784$, and Mexico ranks third lowest at $\$ 2,801$. The median is $\$ 9,336$ per student per year (OECD 2016).

\subsection{Historical Studies}

To provide additional data to compare to the PISA results, the authors examined several other OECD (Organization of Economic Cooperation and Development) studies that measure adult literacy levels by age group and across nations and the IES, National Center for Statistics report NCES 2014-024 Performance of United States 15-Year-Old Students in Mathematics, Science, and Reading Literacy in an International Context. Over the last three decades, the OECD has attempted to measure the relative literacy levels of the 16-65 year old population, across nations, with varying degrees of success. The adult population is divided into five age groups, 16-25, 26-35, 36-45, 46-55, and 56-65 years old. The first survey in the 1990s was the International Adult Literacy Survey, followed by the Adult Literacy and Lifeskills Survey (ALL) in 2003 and 2006, and the third attempt, the Programme for the International Assessment of Adult Competencies (PIAAC), which was designed to make the testing more relevant to the digital information age. (OECD Adult Literacy 2016) The studies measuring adult literacy across age groups and nations are reviewed below. While additional studies were conducted, the United States participated only in the 1994 IALS and the 2003 ALL, therefore, only these studies in were reviewed in this analysis.

\subsubsection{International Adult Literacy Survey}

Figure 1 represents the percentage of the population scoring at IALS literacy level 3 or higher by age group (1994-1995). The figure illustrates that the United States is one of several countries where the younger population of 16-25 year olds scored lower than the older population, which is an indication that the educational rigor and quality has decreased. In fact, the younger, 16-24 year olds scored 12\% lower than the 46-55 year olds in the United States. The younger population, 16-24 in other countries, on average, has increased $20 \%$ over the older population, 46-55. From another perspective, the United States older population (46-55) ranked $4^{\text {th }}$ out of 12 , whereas, the younger population (16-24) ranked $11^{\text {th }}$ out of 12. This represents a significant decrease in the literacy score of the United States' youth, compared to their parents, which is in complete opposition to the increase in literacy of the youth in the vast majority of other countries. As this study was 20 years ago, the indications are the United States literacy rate is still declining when measured against other nations.

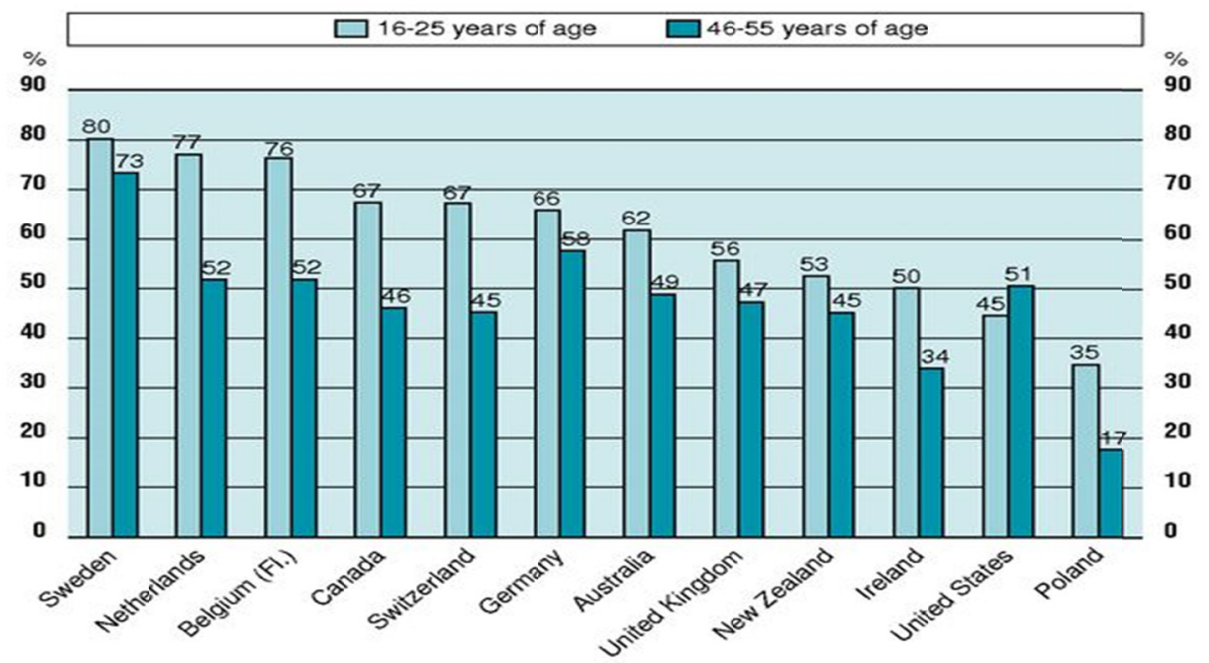

Figure 1. The Percentage of the population scoring at IALS literacy level 3 or higher on the document scale by age group from 1994-1995. (OECD, Educational Attainment of the Adult Population, 2000) 


\subsubsection{The 2003 Adult Literacy and Lifeskills Survey (ALL)}

Literacy was defined in ALL as the knowledge and skills needed to understand and use information from text and other written formats. Numeracy was defined in ALL as the knowledge and skills required to manage mathematical demands of diverse situations." (Institute of Education Science (IES), National Center for Education Statistics (NCES)) The expected outcomes from the ALL Surveys was threefold. It was designed to understand the distribution of literacy and numeracy skills of United States' compared to other nations, determine the relationship of these skills to economic, social, and personal attributes for individuals on a cross-sectional basis, and aggregate these individual skills into the economic and social skills of the nation.

Literacy

\begin{tabular}{|c|c|c|c|}
\hline Country & Score & Country & Score \\
\hline Norway & 293 & Switzerland & 290 \\
\hline Bermuda & 285 & Norway & 285 \\
\hline Switzerland & 274 & Bermuda & 270 \\
\hline Canada & 281 & Canada & 272 \\
\hline United States & 269 & United States & 261 \\
\hline Italy & 228 & Italy & 233 \\
\hline
\end{tabular}

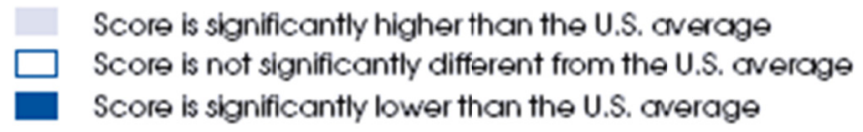

Figure 2. Average literacy and numeracy scores of 16- to 65-year-olds, by country: 2003

IES, NCES, Adult Literacy and Lifeskills Survey (ALL) 2011

As shown in Figure 2, the United States ranked fifth out of the six participating countries in both literacy and numeracy in the 2003 survey. In examining the data from the IALS 1994 and the 2003 ALL studies, there was no significant change in the skill levels in prose and document literacy in any country. (Statistics Canada, OECD Second International ALL Report, 2011). It must be noted that there was only six participants (samples) in the 2003 ALL study and therefore the conclusions are not as robust as larger sample studies

1.4.3 Programme for the International Assessment of Adult Competencies (PIAAC)

Shown in Figure 3, the range of scoring results across the PIAAC numeracy scale for adults 16 to 65 years of age was 246 to 288 . The U.S. average score of 257 was below the PIAAC international average and $17^{\text {th }}$ out of the participating nations. The United States scored higher than 4 nations out of 22 participants.

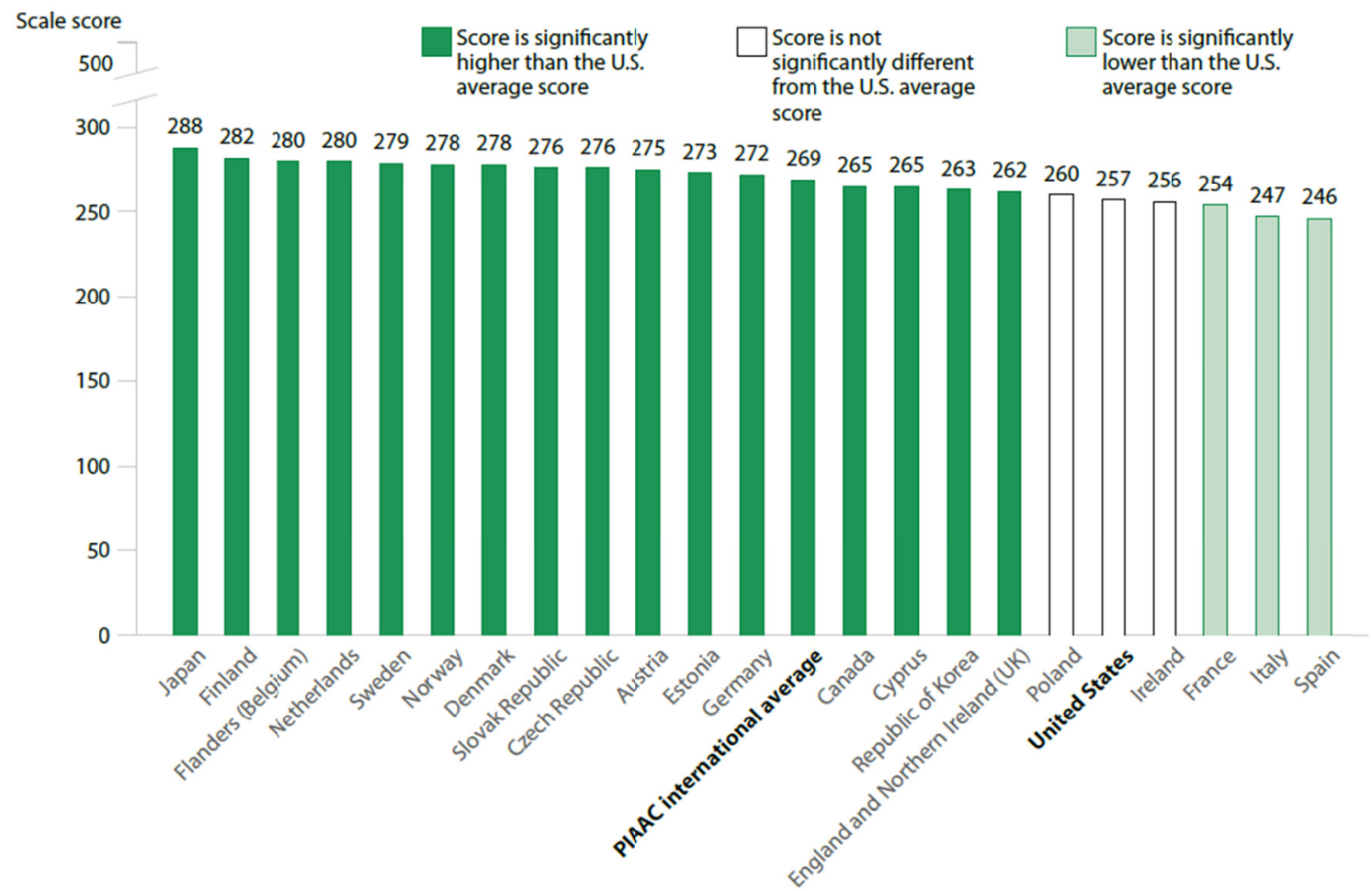

Figure 3. Average scores on the PIAAC numeracy scale for adults age 16 to 65: 2012 and 2014. 
U.S. Department of Education, National Center for Education Statistics, Program for the International Assessment of Adult Competencies (PIAAC), U.S. PIAAC 2012/2014; Organization for Economic Cooperation and Development, PIAAC 2012.

\subsection{Hypothesis and Null Hypothesis}

Hypothesis: If a country scores higher on the PISA Mathematics test, then the higher the country's ten year average GDP growth rate. Null Hypothesis: The country's Mathematics PISA score is unrelated to the country's ten year average GDP growth rate.

\section{Method}

The PISA mathematic scores are a quantifiable aspect of educational analysis. The Programme for International Student Assessment (PISA) measures 15-year-old student performance in 65 nations, include 3 states in the United States, in relation to mathematics, science, and reading. For this study, the authors have focused on the 2012 PISA Mathematics scores. As illustrated by Figure 4, the nations are ranked by scores representing the percentage of students on level 5 and above and the percentage of students below level 2. Shanghai-China ranked at the top of the list with a score of 55. The United States ranked $35^{\text {th }}$ out of the 65 tested in 2012. The PISA scores are compared to the ten year average GDP growth rates of the top five countries and the bottom five countries GDP growth rates shown in the Appendix Table 1. In an effort to provide additional clarity into the possible implications of lower literacy scores, the authors added the 2012 population of each participating country to examine the proportion of the tested population more literate than the United States.

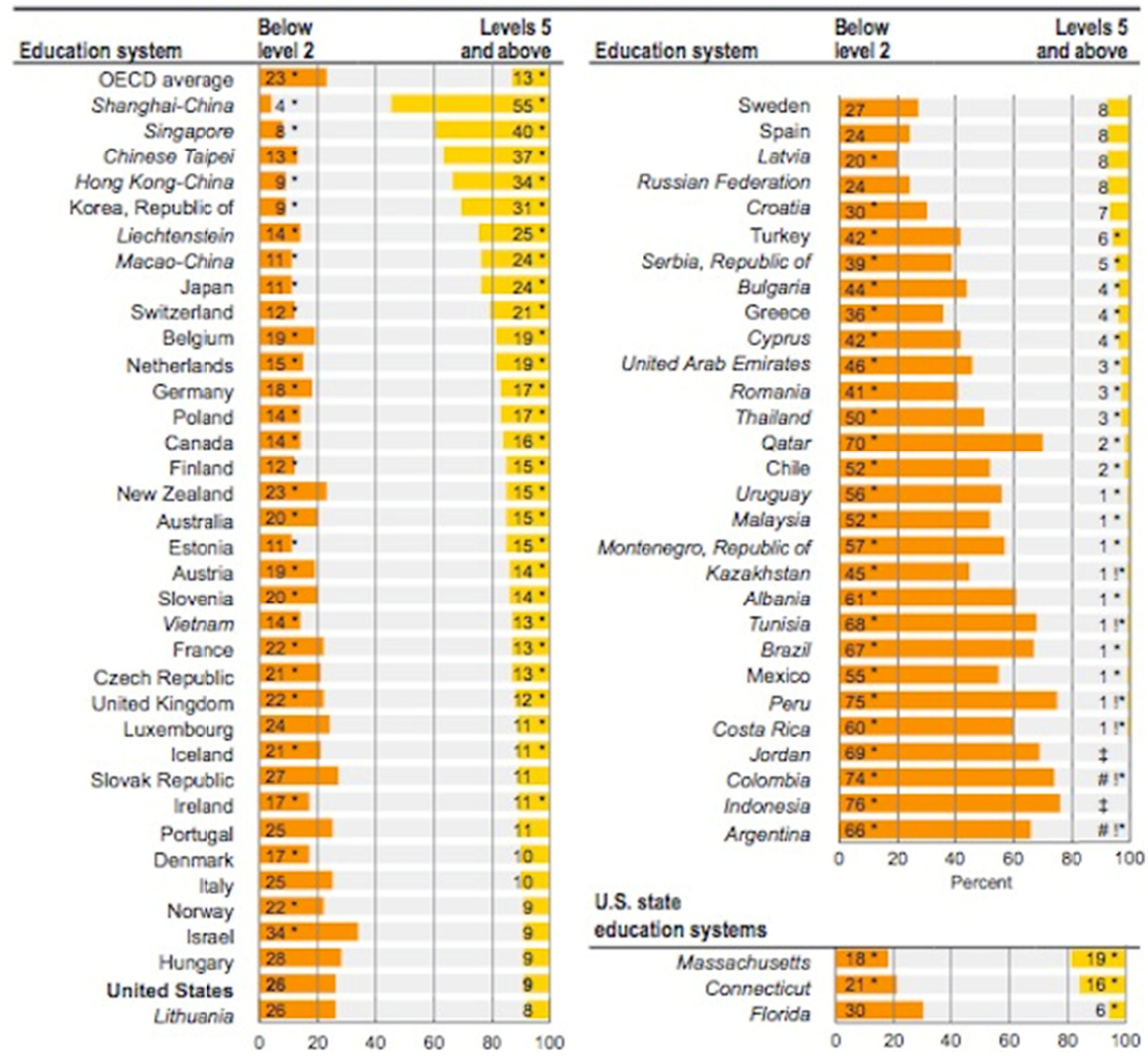

Figure 4. Percentage of 15 -year-old students performing at PISA mathematics literacy proficiency levels 5 and above and below level 2, by education system: 2012 (Fensterwald, 2013) 
Reading-United States. Within the 34 OECD member nations with a combined population of $1,250,450$ people, the United States scored lower in reading than 16 nations with a combined population of $536,064,000$ or $43 \%$ of the population is above the U.S. literacy rate in reading.

Including all 65 nations participating in the PISA 2012 reading the United States scored lower than 25 nations with a combined population of 2,007,058,000 out of the 3,627,853,000 tested or 55.3 percent of the tested population scored higher than the United States in Literacy reading scores.

Mathematics-United States. Within the 34 OECD member nations with a combined population of 1,250,450 people, the United States scored lower than 26 nations with a combined population of $687,391,000$ or $55 \%$ of the OECD population scores higher than the United States in mathematics.

Including all 65 nations participating in the PISA 2012 mathematics, the United States scored lower than 34 participants with a combined population of $2,298,659,000$ out of the $3,627,853,000$ tested or $63.4 \%$ of the tested population scored higher than the United States in mathematics scores.

Science-United States. Within the 34 OECD member nations with a combined population of 1,250,450 people, the United States scored lower than 26 nations with a combined population of $687,391,000$ or $55 \%$ of the OECD population in science.

Including all 65 nations participating in the PISA 2012 science the United States scored lower than 35 nations with a combined population of $2,007,058,000$ out of the $3,627,853,000$ tested or 55.3 percent of the tested population scored higher than the United States in science scores.

\section{Results}

As illustrated in the Appendix Table 1, using the average GDP growth rates of the top 5 and bottom 5 countries from mathematics PISA 2012 scores, both above level 5 and below level 2 results, were compared to the GDP growth rates of the United States. The top five PISA scoring countries have an average 10-year GDP growth rate of $5.1 \%$. The bottom PISA scoring countries have an average 10-year GDP growth rate of $4.7 \%$, both of which are above the United States 10 -year GDP growth rate of $1.5 \%$. Of the 65 participants in the 2012 PISA evaluation, 44 have a higher 10-year GDP growth rate than the United States, while 19 had a lower GDP growth rate. Therefore, the research hypothesis is not valid and the null hypothesis is accepted, that there is no correlation between PISA Mathematics test scores and the GDP growth rate of a country.

\section{Discussion}

While the PISA scores are an important measure of reading, science and mathematics, which indicate one's ability to understand material, illustrate a foundation in scientific principles, and apply logical mathematics in problem solving, it must not be considered in isolation. The Four Pillars of Learning, as defined by UNESCO, include learning to know, learning to do, learning to live together, and learning to be. (UNESCO, 2013) The PISA testing system measures the first and second pillar, which is only two of the four pillars that compose learning. It is fundamental in achieving success in the other two pillars. The authors accept that PISA is not the absolute measure of education, knowledge, tolerance, and wisdom, but it is a strong indication of the foundational education and knowledge of the next generation. There are a multitude of arguments as to the importance of the PISA scores and the conclusions that may be drawn from the results. Some argue that the PISA scores do not accurately reflect student learning in the United States and that there is no correlation between economic growth and the results.

The article, Are International Tests Worth Anything?(Baker, 2007), examined the countries involved in the 1964 First International Mathematics Study (FIMS) and examined several economic measures and found the United States performed better in the following decades than the nations that scored higher than the United States. This article has been quoted and referenced by several authors in discussions on the value of international testing. The article, Are Pisa scores really that important? (Fox, 2013), compares the PISA scores to the number of Nobel Prizes awarded to each country and finds no correlation to the country's PISA scores, as the United States has been awarded more Nobel Prizes than any other nation, since the turn of the century. In addition, the author Jeremy Fox cites comments from Diane Ravitch's Blog in the Huffington Post (Ravitch, 2013) stating that she believes international testing is worthless. Further, Diane Ravitch has been very vocal about the use of international testing scores in the United States, as a political tool, to de-fund public education and privatize education in the United States. (Ravitch, 2013)

On the other side of the argument, some profess that there is a positive relationship between economic growth and the PISA test results. Thus, the lackluster results by students in the United States is paramount. In an effort to address these two opposing hypotheses, the authors ran a sample comparison on the GDP growth rates, as a method to compare economic growth. 
Figure 6 (Ross, 2011) shows the GDP growth rate of the United States, from a 120 year average down to a 10 year average, using data as of 2009. It indicates the slowing GDP growth rate in the United States.

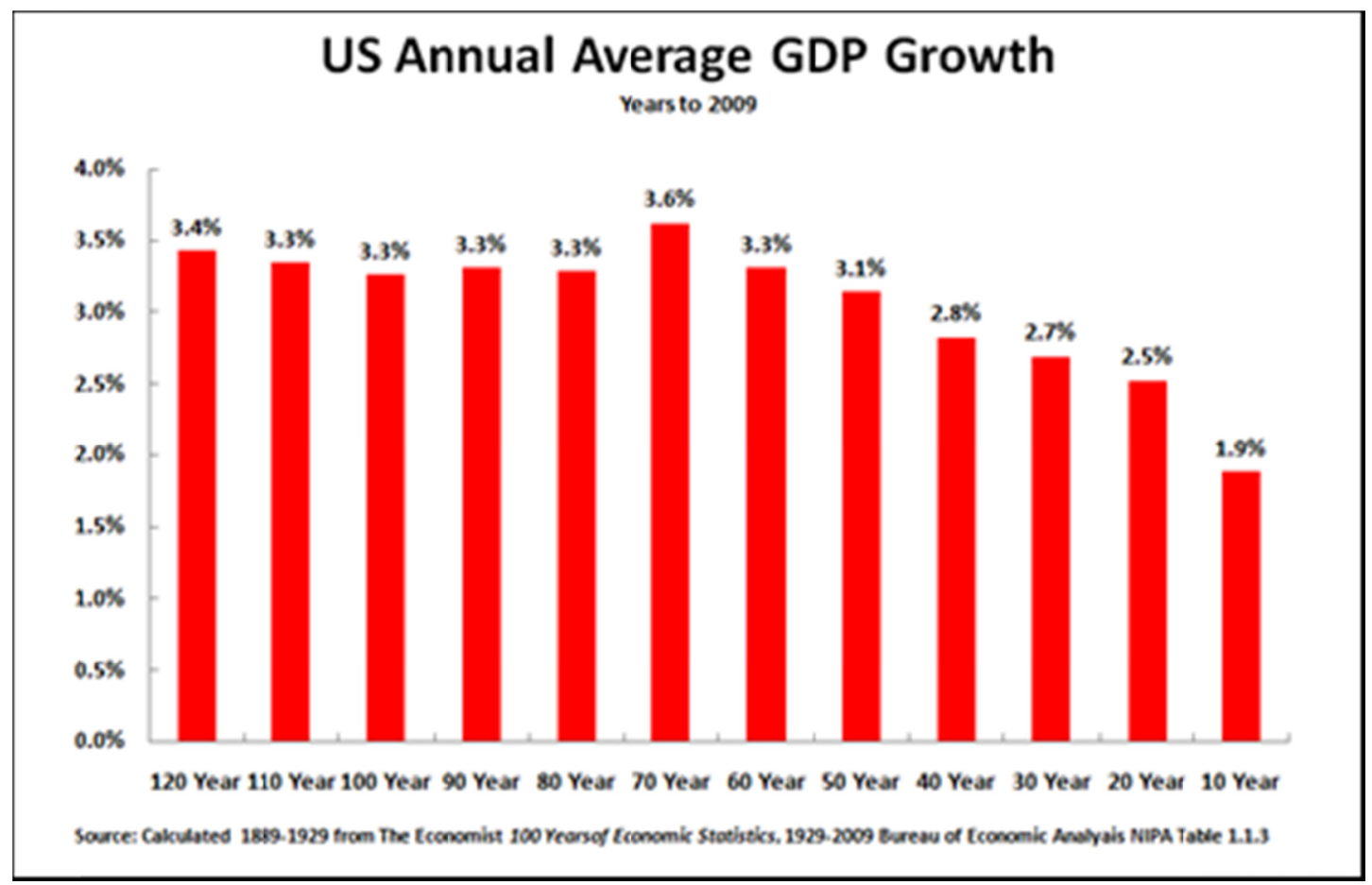

Figure 6. U.S. Annual Average GDP Growth (Ross, 2011)

In fact, as of 2015, the 10 year average annual growth rate in the United States has slowed to just 1.5 percent (Pasquali, 2015). The international academic testing show that as the testing becomes more global, more countries score higher than the United States in mathematics and science. Economic growth of the United States is declining, and the question is why. The authors published a peer reviewed article in 2015, Income Sustainability through Educational Attainment, (Carlson \& McChesney, 2015) which indicated that the individual earnings are closely correlated to the individual's achieved level of educational attainment. However, the research also showed that the standard of living has been declining for over 20 years for seventy percent of the U.S. population. Still, some argue that the academic performance of the present and future generations' holds little meaning, since the United States is the largest economy.

The data, over the years, has illustrated that the test scores of students in the United States are mediocre, at best. While the United States is an undeniable economic powerhouse, the student test scores do not reflect a trend that would indicate that this economic dominance will continue into the future, as many countries are outscoring the United States students in every category. As a country, the United States fails to score in the top quartile in any of the categories, which is alarming. To some, the level of impact, however, is still in question.

While the statistical correlation between test scores and GDP growth has not been proven, the mediocre test results of students in the United States are disquieting. It may prove true that it will take several decades before the correlation becomes statistically evident and, at that point, it may be too late for the United States to recover, if no measures are taken to improve the test scores, at this time. The fact is that the pedestrian educational foundations in the United States are in dire need of improvement, in an effort to compete, in decades to come, on a global level.

\section{References}

Baker, K. (2007). Are International Tests Worth Anything? Phi Delta Kappan, 89(2), 101-104. http://dx.doi.org/10.1177/003172170708900205

Carlson, R., \& McChesney, C. (2015). Income sustainability through educational attainment. The Exchange.

Fensterwald, J. (2013). U.S. scores stagnant, other nations pass us by in latest international test. Retrieved from Ed Source Highlighting Strategies for Student Success:

http://edsource.org/2013/u-s-scores-stagnant-other-nations-pass-by-in-latest-international-comparison/52052

Fox, J. (2013). Are PISA scores really that important? Published on open Democracy: http://www.opendemocracy.net 
Institute of Education Science (IES), National Center for Education Statistics (NCES) Adult Literacy and Lifeskills Survey (ALL) 2011.

Montt, G. (2012). Does money buy strong performancein PISA?. PISA in Focus1 13. www.oecd.org/pisa/infocus

OECD, Adult Literacy. (2016) http://www.oecd.org/edu/innovation-education/adultliteracy.htm Accessed July 7, 2016

OECD. (2000). Educational Attainment of the Adult Population.

OECD (2012). PISA In Focus. Does money buy strong performance in PISA? PISA in Focus1 13. http://dx.doi.org/10.1787/5k9fhmfzc4xx-en

OECD (2016). 2012 Education Spending primary to non-tertiary in U.S. OECD Education Spending

Pasquali, V. (2015). Countries with Highest GDP Growth 2015.

Program for the International Assessment of Adult Competencies (PIAAC), U.S. PIAAC 2012/2014.

Ravitch, D. (2011). Diane Ravitch's Blog. Retrieved from https://dianeravitch.net/2013/12/03/my-view-of-the-pisa-scores/

Ravitch, D. (2013). The Reign of Error: The Hoax of the Privatization Movement and the Danger to America's Public Schools. New York: Knopf 2013

Ravitch, D. (2013) What You Need to Know About the International Test Scores. The Huffington Post (Updated February 2, 2014).

Statistics Canada, OECD Second International ALL Report,2011

UNESCO. (2013). The four pillars of learning. Retrieved from United Nations Educational, Scientific, and Cultural Organization:

http://www.unesco.org/new/en/education/networks/global-networks/aspnet/about-us/strategy/the-four-pillars-of-lea rning 


\section{Appendix}

Table 1. 2012 PISA Mathematics scores and 10-year average annual GDP growth rates from 2006 to 2015 (Authors using 2012 PISA and (Pasquali 2015)

\begin{tabular}{|c|c|c|c|}
\hline Country & $\begin{array}{l}\text { Percent } \\
\text { Below level } \\
2\end{array}$ & $\begin{array}{l}\text { Percent } \\
\text { Above level } \\
5\end{array}$ & $\begin{array}{l}10 \text { year Average } \\
\text { GDP growth }\end{array}$ \\
\hline China (Shanghai) & 4 & 55 & $9.5 \%$ \\
\hline Singapore & 8 & 40 & $5.3 \%$ \\
\hline Taiwan (Taipei) & 13 & 37 & $3.6 \%$ \\
\hline China (Hong Kong) & 9 & 34 & $3.5 \%$ \\
\hline Korea & 9 & 31 & $3.7 \%$ \\
\hline Liechtenstein & 14 & 25 & \\
\hline China (Macao) & 11 & 24 & $9.5 \%$ \\
\hline Japan & 11 & 24 & $0.6 \%$ \\
\hline Switzerland & 12 & 21 & $1.8 \%$ \\
\hline Belgium & 19 & 19 & $1.0 \%$ \\
\hline Netherlands & 15 & 19 & $0.9 \%$ \\
\hline Germany & 18 & 17 & $1.5 \%$ \\
\hline Poland & 14 & 17 & $3.8 \%$ \\
\hline Canada & 14 & 16 & $1.7 \%$ \\
\hline Finland & 12 & 15 & $0.5 \%$ \\
\hline New Zealand & 23 & 15 & $2.0 \%$ \\
\hline Australia & 20 & 17 & $2.8 \%$ \\
\hline Estonia & 11 & 15 & $1.9 \%$ \\
\hline Austria & 19 & 14 & $1.4 \%$ \\
\hline Slovenia & 20 & 14 & $0.9 \%$ \\
\hline Vietnam & 14 & 13 & $6.0 \%$ \\
\hline France & 22 & 13 & $0.8 \%$ \\
\hline Czech Republic & 21 & 13 & $1.9 \%$ \\
\hline United Kingdom & 22 & 12 & $1.1 \%$ \\
\hline Luxembourg & 24 & 11 & $1.7 \%$ \\
\hline Iceland & 21 & 11 & $1.5 \%$ \\
\hline Slovak Republic & 27 & 11 & $3.5 \%$ \\
\hline Ireland & 17 & 11 & $1.0 \%$ \\
\hline Portugal & 25 & 11 & $-0.1 \%$ \\
\hline Denmark & 17 & 10 & $0.4 \%$ \\
\hline Italy & 25 & 10 & $-0.4 \%$ \\
\hline Norway & 22 & 9 & $1.2 \%$ \\
\hline Israel & 34 & 9 & $3.9 \%$ \\
\hline Hungary & 28 & 9 & $0.5 \%$ \\
\hline United States & 26 & 9 & $1.5 \%$ \\
\hline Massachuetts & 18 & 19 & \\
\hline Connecticut & 21 & 16 & \\
\hline Florida & 30 & 6 & \\
\hline Lithuania & 26 & 8 & $2.7 \%$ \\
\hline Sweden & 27 & 8 & $2 \%$ \\
\hline Spain & 24 & 8 & $0.5 \%$ \\
\hline Latvia & 20 & 8 & $2.0 \%$ \\
\hline Russian Federation & 24 & 8 & $2.8 \%$ \\
\hline Croatia & 30 & 7 & $-0.1 \%$ \\
\hline Turkey & 42 & 6 & $3.8 \%$ \\
\hline Serbia, Republic of & 39 & 5 & $1.3 \%$ \\
\hline Bulgaria & 44 & 4 & $2.1 \%$ \\
\hline Greece & 36 & 4 & $-1.4 \%$ \\
\hline Cyprus & 42 & 4 & $0.2 \%$ \\
\hline UAE & 46 & 3 & $3.6 \%$ \\
\hline Romania & 41 & 3 & $2.5 \%$ \\
\hline Thailand & 50 & 3 & $3.3 \%$ \\
\hline Qatar & 70 & 2 & $13.0 \%$ \\
\hline Chile & 52 & 2 & $4.0 \%$ \\
\hline Uruguay & 56 & 1 & $5.0 \%$ \\
\hline Malaysia & 52 & 1 & $4.9 \%$ \\
\hline Montenegro, Republic & 57 & 1 & $3.3 \%$ \\
\hline Kazakhstan & 45 & 1 & $5.9 \%$ \\
\hline Albania & 61 & 1 & $3.5 \%$ \\
\hline Tunisia & 68 & 1 & $3.3 \%$ \\
\hline Brazil & 67 & 1 & $3.0 \%$ \\
\hline Mexico & 55 & 1 & $2.5 \%$ \\
\hline Peru & 75 & 1 & $6.2 \%$ \\
\hline Costia Rica & 60 & 1 & $4.4 \%$ \\
\hline Jordan & 69 & & $4.7 \%$ \\
\hline Columbia & 74 & & $4.7 \%$ \\
\hline Indonesia & 76 & & $5.8 \%$ \\
\hline Argentina & 66 & & $3.8 \%$ \\
\hline
\end{tabular}

\section{$(\mathrm{cc}) \mathrm{EY}$}

This work is licensed under a Creative Commons Attribution 3.0 License. 